При цьому необхідно визначити сутність і зміст таких педагогічних категорій, як «патріотизм», «виховання», «виховний ідеал», враховувати соціально-психологічні особливості розвитку особистості дітей дошкільного віку. Патріотизм є складною інтегративною складовою особистості українського громадянина, що передбачає любов до України, повагу до вітчизняної історії, національно-історичних традицій, святинь українського народу, місця свого народження та постійного місця проживання; цілеспрямоване оволодіння особистістю патріотичними знаннями як основи іiі патріотичного виховання.

Ключові слова: виховання, патріотизм, громадянське виховання, особистість, загальнолюдські цінності, духовні цінності, національне виховання.

Submitted on February, 20, 2017

Reviewed by Doctor of Pedagogy O. Kovshar

UDC: $37.013 .42: 159.922 .76-056.49$

DOI: https://doi.org/10.24195/2414-4665-2017-2-14

\author{
Svitlana Hryshchenko, \\ Doctor of Pedagogy, associate professor, \\ Department of Social Work, \\ Chernihiv National Pedagogical University named after T. H. Shevchenko, \\ 53, Hetmana Polubotka Str., Chernihiv, Ukraine
}

\title{
SPECIFICS OF FUTURE TEACHERS' WORK ON RE-EDUCATING DIFFICULT PUPILS OF SECONDARY SCHOOLS
}

The article focuses on the essence of future teachers' practical activity when working with difficult pupils at secondary schools. Based on certain scientific approaches, methods and techniques, the content of teaching instructions worked out in view of the specifics of educating difficult children is outlined. Suggested teaching instructions are based on the principles of re-education, personality correction, regular monitoring of the behavior norms acquisition, objective tools of influencing, teacher's control of his/her own attitude to pupils, individualization. The objectives of each component are presented in the article in details. The paper includes a list of methods and techniques according to the specifics of future teachers' work with difficult pupils and the overall results of their implementation in the school work.

Keywords: educating difficulty, difficult pupils, re-education, teachers, work specifics.

\section{Introduction}

In the twenty-first century, in the times of economic instability, changes of the fundamental moral, spiritual values and beliefs in the work of secondary school teachers of Ukraine are observed. Ukrainian scholars argue that pupils often perceive and acquire negative trends of behavior.

Educating difficulty, pedagogical neglect of children has become nowadays commonplace. Therefore, correction of these phenomena, re-education of juvenile delinquents is a key objective of secondary schools teachers.

It is essential for teachers to know the reasons of pupils' educating difficulty, to be able to influence on the child, to carry out preventive or correctional work, which could help decrease the number of delinquency caused by pupils' aggressiveness and emotional disturbance.

The problem of juvenile behavior deviations attracts attention of the scholars who thoroughly study its nature (A. Kapska, V. Orzhekhovska, L. Pidlypna, M. Sturova, O. Shestopalova, O. Shynkarenko, H. Fedoryshyn et al.). Important aspects of school adaptation of difficult children were studied by O. Hlavnyk, S. Maksymenko, K. Maksymenko. The article aims to reveal the practical aspects of teachers' educational work with difficult children. The tasks are as follows: to study the specifics of educational work with difficult children; to analyze instructions on teaching techniques concerning teachers' work on reeducation of difficult pupils of secondary schools.

\section{Methodology}

At the theoretical level, we employed the following methods: systematic analysis of educational literature on the problems of educating difficulties; logical analysis when studying theoretical background of the issue; theoretical modeling, aimed to develop instructions on teaching techniques concerning teacher's activity when re-educating difficult pupils; the empirical one - diagnostic (surveys, questionnaires) to study readiness of future teachers of various disciplines to work with difficult pupils of secondary schools; classroom observation; praximetrics: study of curricula, norms, national standards and programs; pedagogical experiment (summative and formative stages); methods of mathematical statistics. We carried out a survey of master students of three universities in the 2015-2016 academic years aimed to find out methods, techniques, components of re-educating difficult pupils of secondary schools. The scope of the study involved 124 students. The study included the summative stage (control group consist- 
ed of 60 students, experimental group - of 64 students) and the formative stage (control group - 60 students, experimental group - 62 students).

\section{Discussion}

If there are any deviations in pupil's behavior, the teacher should answer two questions: is these deviations are of random or permanent character, if the pupil has got any diseases that could lead to these behavior deviations. And only after doing so they should work out the ways to eliminate such deviations. Scholars distinguish the following basic reasons of children's educating difficulty formation: 1. Psycho-biological reasons: hereditary factor, peculiarities of children's mind. 2. Social reasons: family, school collective, peer collective, a circle of friends, media, street. Knowledge of these preconditions is important for future teacher's further work with difficult children, which is based on the principle of dual and opposing pedagogical influence: blocking of the negative and development of the positive in secondary schools pupils.

The essence of re-educating should be defined as a method of resolving major contradictions in pupils' inner world: "1) contradiction between major positive qualities and major personality drawbacks; 2) collision between negative qualities, solving it is associated with great difficulties and requires long-term educational impact; 3) contradiction between the needs of positive impressions, favorable state of the group and negative qualities that prevent from taking some place, gaining prestige; 4) contradiction between the objectives and the results of the activity targeted at achieving them, i.e. between consciousness and behavior, between the desired, expected and achieved" [5, p. 123].

As for the nature of educating difficulties, the following may be concluded: when natural contradictions between the attitude to the world and to oneself become a conflict, deepen and worsen, but are not solved, there are internal prerequisites for behavior deviations, and then for developing the drawbacks of negative qualities. Since inadequate attitude to oneself is found rather often, difficult pupils of secondary schools reveal manifestation of such negative qualities as over-confidence, lack of selfdiscipline, self-criticism, demands to oneself, subjectivity in assessing others, search for dubious pleasures. As a result, attitude to other people, especially to parents and teachers is changing.

Working with difficult pupils in the school shows that two opposing concepts and two tactics have emerged in the process of choosing the techniques of personality correction. The first one, the most common, is characterized by the fact that a difficult child is considered to be bad, hopeless. They are treated in an unfriendly manner, their behavior deviations are often focused, they are condemned and punished. Positive personal qualities are out of the attention focus. Consequently, anger, cruelty, desire to revenge teachers who hurt them, and peers who were indifferent to their problems arise in such children. This approach is called a tactics of indifferent fixing of offenses and conviction of the pupils who are considered difficult.
Another conception implies that every secondary school pupil has a desire for good, and the bad per se depresses him/her and makes him/her suffer. But the child is unable to focus his/her attention on correcting the errors independently. The pupil needs some help of a good and thoughtful teacher who wants to help. In addition, there is always a struggle of positive and negative trends in the child's mind. The inclusion of a child in doing morally valuable acts reinforces positive trends and painless displacement of the negative ones. This conception is known to have been implemented in the educational system of A. Makarenko and is widely used by qualified pedagogues. The tactics based on this conception could be called a tactics of projecting positive qualities of a personality and organizing the experience of his/her correct behavior. It is based on the principles of educational optimism, respect for children, understanding their mental state, interest in their lives, which are particularly important in dealing with difficult children [6, p. 13].

Pedagogical literature review allowed us to define the following stages of re-education of a difficult pupil of secondary school: 1) the first stage - establishing a contact with the pupil, awakening his/her desire to change; 2 ) the second stage - a process of the improving and consolidating of positive qualities is observed. Under the influence of various techniques of pedagogical influence, used in interaction with all educational work, the pupil is being gradually involved into the life and work of the group. This condition is a kind of training for the ability to establish healthy relationships with teachers, pupils, parents; 3) the third stage - is a gradual increase in positive qualities' strength and stability due to the pupil's effort, mastering the correct behavior experience [1, p. 34].

Summarizing the experience of practitioner-teachers and master students, who repeatedly had teaching practice, some general trends and common techniques used in the work on re-educating difficult pupils can be distinguished: 1) organization of positively directed activity when negativity is blocked and all the attention is fixed on positive forms of behavior; 2) feasibility of the educational plan objectives and requirements for each pupil; 3) graduality, specification of objectives because a pupil is not always able to fulfill complex requirements immediately; 4) enhanced differentiation of means and methods of influence adequate to each pupil's individual needs; 5) systematic monitoring of the acquisition of behavior norms' mastery, opportune assessment of achievements, friendly support in overcoming deficiencies; 6) objective influence measures [5, p. 76]

Herewith, master students and secondary school teachers have to take into account the fact that positive orientation of difficult pupil's re-education is possible only if confidential relations between a child and a specialist are established. In fact, maintaining such a complex psychological state as being educated is the key challenge for both teachers and master students who practice teaching at all stages of re-educating. 
It is worth mentioning that pupils' moral development is defined not only by the nature of the wide system of social relations in which they are included, but also by the system of interpersonal relationships which take place in their immediate environment, the microenvironment. Personality traits are not only developed and revealed in relationships with other people, but can be changed through interaction with people. Studying pupils' attitude towards adults, peers, themselves, the future teacher is able to determine the source of positive or negative impact, to judge their strength, stability and to build his/her tactics of managing them on this basis.

An important aspect of re-educating difficult pupils of secondary school is individualization. This is not only a thorough knowledge of each pupil, but careful attitude to an individual. Since, as I. Kon argues, "personal approach in education does not only mean taking into account pupil's individual characteristics that are different. It is, first of all, consistent treating him/her as an individual, as a responsible and self-conscious subject" [2, p. 179].

To solve complex tasks when re-educating difficult children, future teachers should have appropriate knowledge and skills. They include: 1. Scientific pedagogical thinking, which allows the teacher to feel confident in the most difficult teaching situations, quickly realize what the major educational task is, determine effective means of influence, use the opportunities of microenvironment, society and encourage the child's selfeducating. 2. High level of pedagogical literacy and psychological intuition are necessary to determine the reasons of educating difficulties, levels of children educatedness, understand peculiarities of their behavior in different situations. 3. Pedagogical tact and pedagogical ethics which contribute to developing normal relations with difficult children, provide an opportunity of mutual educating, self-educating, successful elimination of the causes of educating difficulties. 4. Developed organizational skills which allow to engage parents, community and other specialists in difficult children re-education and to use all educational opportunities. 5. The method and style of education, worked out by the future teacher based on personal experience, taking into consideration talents and abilities combined with his/her individuality [4, p. 23].

It should be noted that the latter is of particular importance when it comes to individual and personal approach to difficult pupils. The personal approach, according to its very definition, is mutual relationships of two individuals, where future teacher's individuality is not less significant than the pupil's. Often teachers and future teachers look for the cause of the conflict in the pupil, although sometimes the main reason of the conflict is the adult. Hence, it can be said that only the teacher who develops spiritually faster than his/her pupils can re-educate. In this regard, a group of individual professional skills that are the most important in correctional and educational work can be distinguished: - personality traits associated with the development of empathy in future teachers - the ability to understand and feel the inner world and the inner state of another person and appreciate his/her feelings; - the ability to influence upon the pupil actively, personality dynamism; - future teacher's communicative skills: being attentive, observant, flexible, etc.; the ability of social perception (face reading); the ability to understand, not only to see, but simulate adequately pupil's personality, its mental state judging by external features; the ability to present oneself when communicating with children; skills of verbal and nonverbal interaction with the pupil; readiness for pedagogical creativity, ability to improvise (change one's behavior depending on the environment, situation, the moment of decision making); - reflective skills: realizing one's own true motives of educational activity, their actions; the ability to separate one's own difficulties and problems from the difficulties and problems of pupils; assessing the consequences of one's own value-based impact on the pupils [3, p. 123].

Taken together, these qualities reflect individuality and are the basis for individual teaching activity style, which, undoubtedly, has a positive impact on the whole correctional and educational process of working with difficult children.

The following principles should be employed in work with difficult pupils: connection of re-educating with productive labor; organization of pupils group that would provide a positive impact on them; reliance on pupil's positive qualities and positive social experience; organic combination of respect for pupils with the existing system of requirements; unity and consistency of pedagogical impacts; individual approach to it; humane and objective attitude to the pupil during his re-education; restraint, impermissibility of teacher's affective behavior.

We conducted an initial assessment of values; according to its results the quantitative and qualitative analysis of the formed levels of future teachers' readiness to work on re-educating difficult pupils was carried out, which proved that the respondents of experimental (EG) and control (CG) groups were at relatively similar levels of readiness: most participants of the experiment had elementary $(\mathrm{EG}-28 \%, \mathrm{CG}-30 \%)$ and basic (EG $35 \%, \mathrm{CG}-38 \%$ ) levels; sufficient level was found in $20 \%$ of EG and $22 \%$ of CG; the high one $-17 \%$ of EG, $10 \%$ - in CG.

Analysis of formative experiment's results, generalization of experience of teachers and master students, who were working in the experimental groups, study of the dynamics of qualitative and quantitative changes in the level of developing readiness for work on re-educating difficult pupils also confirm a working hypothesis of this study on the importance and usefulness of using methods and teaching instructions concerning the significance of teachers' and master students' work in secondary schools.

We will also reveal the techniques that contribute to the formation of ethical behavior and the accumulation of social and positive experience: 1 . Organization of academic success (that is to provide support for the pupil until he/she achieves success in training). 2. Moral support (its essence is to increase pupil's authority among his/her peers and to strengthen his/her self-confidence). 3. Persuading (explanation and 
proof of correct behavior). 4. Trust (to entrust a pupil with some responsible assignments). 5. Belief in better outcomes (the teacher claims that he/she expects significant progress from the pupil, which contributes to the developing of learning motivation).

For future teachers' work on re-educating difficult pupils of secondary schools, it is essential to know techniques with covert action: 1. Parallel pedagogical action (punishing the whole group because of a violation of rules committed by one of the pupils so that the group could influence on that guilty). 2. Hint (a pupil is given an opportunity to realize his/her fault, without accusing or punishing). 3. Tender reproach (conversation in a friendly tone, where conviction is rather mild). 4. Artificial indifference (such a teaching situation is provided, as if no one pays attention to the pupil's pranks, so an awkward position of the offender gives him/her a feeling of disappointment and frustration). 5. Irony (a guilty pupil is made look ridiculous, but, of course, without offense to his/her personality).

The balanced combination of individual, collective and educational actions, the use of different methods, techniques and types in extracurricular activities in correctional educational work with children with deviant behavior increases its effectiveness, helping make the process of overcoming the developmental drawbacks and deviations in children's behavior real and effective, and the task of developing personality's positive qualities and integration into the society becomes feasible.

The following teaching guidelines for work on reeducating difficult children based on the analysis of educational literature can be offered: 1. Educational and social neglect of pupils with deviant behavior can be successfully overcome if the forms and methods of educational activities are differentiated depending on the specific conditions of his/her life. 2. It is necessary to apply individual approach to each pupil. 3. It is important to

\section{REFERENCES}

1.Maksymenko, S., Maksymenko, K., Hlavnyk, O. (2003). Adaptatsiia dytyny do shkoly [Adapting child to school]. Kyiv [in Ukrainian].

2.Pidlypna, L. V. (2005). Adaptatsiia: 5-ti klasy [Adaptation: 5th grades]. Ivano-Frankivsk [in Ukrainian].

3. Orzhekhovska, V. M. (1994). Psykholohopedahohichni osnovy diahnostyky pravoporushen ta pryiomiv vykhovnoii korekysii [Psycho-pedagogical foundations of delinquency diagnostics and methods of educational correction]. Kyiv [in Ukrainian].

4.Sturova, M. P. (1999). Deviantnoye povedeniye nesovershennoletnikh kak pedagogicheskaya problema

\section{ЛІТЕРАТУРА}

1.Адаптація дитини до школи / [упорядн. : С. Максименко, К. Максименко, О. Главник]. - К., 2003. $-144 \mathrm{c}$.

2.Адаптація : 5-ті класи / [під ред. Л. В. Підлипна]. - Івано-Франківськ, 2005. - 321 с. find common language with the pupils, to be able to understand their problems. 4 . The power of a modern teacher lies in recognizing and respecting the personality of a pupil, encouraging free development and improvement of his/her mental world. 5. It is important to make use of methods and techniques of educational and corrective work with difficult children. 6 . A teacher should be constantly developing and improving personality, since "a personality is educated by a personality". 7. It is necessary to co-operate with the parents of such pupils.

\section{Conclusions}

Difficult pupils are children with some manifestations of deviant behavior.

Pupil's educating difficulties is a conscious or nonconscious resistance to pedagogical impact caused by various reasons, including educational shortcomings of teachers, parents, defects of mental and social development, character traits, other personal characteristics of pupils, which complicate social adaptation, learning school subjects and acquiring social roles.

Teaching instructions help teachers, future teachers and difficult pupil themselves to understand each other better and find common ground. It is noteworthy that the specifics of educational work with difficult pupils are the following: reeducation of personality, systematic monitoring of pupil's mastery of behavior standards, objective means of influence, teachers' and future teachers' analysis and control of their own attitude to a child, individualization.

The obtained research results at the pre-final stage of pedagogical experiment demonstrated the feasibility of the implementation of the suggested instructions concerning training future teachers for work with difficult secondary school pupils into educational process of higher educational institutions.

The prospects for further research involve the study of the methods of educational correction of difficult pupils of secondary schools.

[Deviant behavior of juveniles as a pedagogical problem]. Pedagogika - Pedagogy, 7, 38-41 [in Russian].

5.Kapska, A. Y. (Eds.). (2000). Tekhnolohii sotsialno-pedahohichnoi roboty [Technologies of social and educational work]. Kyiv [in Ukrainian].

6. Shestopalova, O. (2000). Adyktyvna povedinka pidlitka: sutnist ta mozhlyvosti psykhokorekrsii [Adolescents' addictive behavior: the nature and possibilities of psychocorrection]. Ridna shkola - Mother school, 9, 2730 [in Ukrainian].

3. Оржеховська В. М. Психолого-педагогічні основи діагностики правопорушень та прийомів виховної корекції / В. М. Оржеховська. - К., 1994. - 156 с. 
4. Стурова М. П. Девиантное поведение несовершеннолетних как педагогическая проблема / М. П. Стурова // Педагогика. - 1999. - № 7. - С. 38-41.

5. Технології соціально-педагогічної роботи / [за ред. А. Й. Капської]. - К. : УДЦССМ, 2000. - 305 с.
6. Шестопалова О. Адиктивна поведінка підлітка : сутність та можливості психокорекції / О. Шестопалова // Рідна школа. - 2000. - № 9. - С. 27-30.

Світлана Владиславівна Грищенко, доктор педагогічних наук, дочент, професор кафедри соиіальної роботи, Чернігівський національний педагогічний університет імені Т. Г. Шевченка, вул. Гетьмана Полуботка, 53, м. Чернігів, Украӥна

\section{СПЕЦИФІКА РОБОТИ МАЙБУТНІХ УЧИТЕЛІВ У ПРОЦЕСІ ПЕРЕВИХОВАННЯ ВАЖКОВИХОВУВАНИХ УЧНІВ ЗАГАЛЬНООСВІТНІХ НАВЧАЛЬНИХ ЗАКЛАДІВ}

В XXI столітті, в умовах економічної нестабільності, школярі часто сприймають і засвоюють негативні тенденції поведінки. Важковиховуваність, педагогічна занедбаність дітей стала звичним явищем. Тому корекція цих явищ $\epsilon$ першочерговим завданням учителів шкіл. Метою статті є розкриття практичних аспектів освітньої роботи майбутніх учителів з важковиховуваними дітьми. Завдання дослідження: дослідити специфіку освітньої роботи 3 важковиховуваними учнями; проаналізувати методичні рекомендації щодо діяльності вчителів в процесі перевиховання важковиховуваних учнів загальноосвітніх навчальних закладів. Було використано такі методи дослідження: системний аналіз педагогічної наукової літератури 3 проблем важковиховуваності, логічний метод, теоретичне моделювання; емпіричні: діагностувальні (опитування, анкетування), спостереження за освітнім процесом; праксиметрії: вивчення навчальних планів, нормативів, державних стандартів, програм; педагогічний експеримент (констатувальний та формувальний етапи); методи математичної статистики. Нами було проведено анкетування студентів магістратури трьох вищих навчальних закладів у 2015-2016 навчальних роках із метою виявлення методів, прийомів, складових процесу перевиховання важковиховуваних учнів загальноосвітніх навчальних закладів. У дослідженні взяли участь 124 студента. За результатами початкового зрізу показників було здійснено кількісний та якісний аналіз сформованості рівнів підготовленості майбутніх учителів до роботи 3 перевиховання важковиховуваних учнів, який засвідчив, що респонденти експериментальної та контрольної груп перебували на відносно однакових рівнях підготовленості. Аналіз результатів формувального експерименту, узагальнення досвіду вчителів i студентів магістратури, які працювали в експериментальних групах, вивчення динаміки якісних і кількісних змін у рівнях сформованості готовності до роботи 3 перевиховання важковиховуваних учнів також підтверджують робочу гіпотезу дослідження про важливість і доцільність використання методики та методичних рекомендацій щодо роботи вчителів і студентів магістратури в роботі шкіл.

Ключові слова: важковиховуваність, важковиховувані учні, перевиховання, вчителі, специфіка роботи.

Submitted on February, 22, 2017 